\title{
HIBAH TANAH PEMERINTAHAN KABUPATEN/KOTA KEPADA WARGA NEGARA INDONESIA
}

\author{
Urip Santoso \\ Fakultas Hukum Universitas Airlangga Surabaya \\ e-mail: urip_sts@yahoo.com
}

\begin{abstract}
ABSTRAK
Status tanah yang dapat dikuasai oleh Pemerintah Kabupaten/Kota adalah Hak Pakai dan Hak Pengelolaan. Tanah Hak Pakai dan Hak Pengelolaan yang dikuasai tersebut tidak dapat dipindahtangankan dalam bentuk apapun kepada pihak lain, termasuk dihibahkan. Tanah Hak Pakai dan Hak Pengelolaan tersebut tidak memenuhi syarat sahnya pemindahtanganan, yaitu syarat materiil dan syarat formal untuk dihibahkan kepada warga negara Indonesia. Pemerintah Kabupaten/Kota tidak mempunyai kewenangan memindahkan tanah yang dikuasainya kepada pihak lain dan hibah tanah Pemerintah Kabupaten/Kota kepada pihak lain adalah tidak sah.

Kata Kunci: tanah, pemerintah daerah, hibah.

\section{ABSTRACT}

The status of land that can be controlled by the district or city government is the Right to Use and Right to Manage of Land. That kind of land are not transferable in any form to any other party, including donated. That kind of land are not legitimately qualified for the transfer process, i.e. the terms and conditions to be granted to Indonesian citizens. The district or city government does not have the authority to transfer the acquisition of land to another party and so does county or city government may not be donating land to another party.
\end{abstract}

Keywords: land, local government, transfer.

\section{PENDAHULUAN}

Hukum Tanah Nasional diatur dalam UndangUndang No. 5 Tahun 1960 tentang Peraturan Dasar Pokok-pokok Agraria, atau lebih dikenal dengan sebutan Undang-Undang Pokok Agraria (yang selanjutnya disebut UUPA). UUPA merupakan pelaksanaan Pasal 33 ayat (3) Undang-Undang Dasar Negara Republik Indonesia Tahun 1945 dan berlaku sejak tanggal 24 September 1960.

Dalam Hukum Tanah Nasional diatur hak atas tanah. Hak atas tanah merupakan hak yang memberi wewenang kepada pemegang haknya untuk mempergunakan dan/atau mengambil manfaat dari tanah yang dikuasainya. Kata mempergunakan mengandung pengertian bahwa hak atas tanah untuk keperluan mendirikan bangunan, sedangkan kata mengambil manfaat mengandung pengertian bahwa hak atas tanah untuk keperluan pertanian, perikanan, peternakan, dan perkebunan.

Hak atas tanah disebutkan dalam Pasal 16 ayat (1) dan Pasal 53 ayat (1) UUPA. Pasal 50 ayat (1) UUPA menegaskan bahwa ketentuan lebih lanjut mengenai
Hak Milik diatur dengan Undang-Undang. UndangUndang tentang Hak Milik yang diperintahkan oleh Pasal 50 ayat (1) UUPA sampai sekarang belum terbentuk. Pasal 50 ayat (2) UUPA menegaskan bahwa ketentuan lebih lanjut tentang Hak Guna Usaha, Hak Guna Bangunan, Hak Pakai, dan Hak Sewa Untuk Bangunan diatur dengan peraturan perundangan. Peraturan perundangan yang diperintahkan oleh Pasal 50 ayat (2) UUPA, Peraturan Pemerintah No. 40 Tahun 1996 tentang Hak Guna Usaha, Hak Guna Bangunan, dan Hak Pakai atas Tanah.

Macam hak atas tanah yang bersifat tetap disebutkan dalam Pasal 16 ayat (1) UUPA merupakan Hak Milik, Hak Guna Usaha, Hak Guna Bangunan, Hak Pakai, Hak Sewa Untuk Bangunan, Hak Membuka Tanah, dan Hak Memungut Hasil Hutan. Macam hak atas tanah yang bersifat sementara disebutkan dalam Pasal 53 ayat (1) UUPA merupakan Hak Gadai, Hak Usaha Bagi Hasil, Hak Menumpang, dan Hak Sewa Tanah Pertanian. 
Hak atas tanah dapat dimiliki atau dikuasai oleh perseorangan warga negara Indonesia atau orang asing yang berkedudukan di Indonesia. Hak atas tanah juga dapat dimiliki atau dikuasai oleh badan hukum publik atau badan hukum privat, atau badan hukum Indonesia atau badan hukum asing yang mempunyai perwakilan di Indonesia.

Badan hukum publik atau badan hukum Indonesia yang dapat menguasai hak atas tanah, antara lain Pemerintah Kabupaten atau Kota. Dalam peraturan perundang-undangan ditetapkan bahwa status tanah yang dapat dikuasai oleh Pemerintah Kabupaten/ Kota adalah Hak Pakai dan Hak Pengelolaan. Hak Pakai dan Hak Pengelolaan yang dikuasai oleh Pemerintah Kabupaten/Kota merupakan barang milik Pemerintah Kabupaten/Kota. Barang milik Pemerintah Kabupaten/Kota berupa benda bergerak, misalnya kendaraan bermotor, dan benda tidak bergerak, misalnya hak atas tanah dan/atau bangunan.

Pemerintah Kabupaten atau Kota mempunyai kewenangan mengelola barang milik daerahnya. Pengelolaan barang milik daerah meliputi perencanaan kebutuhan dan penganggaran, pengadaan, penggunaan, pemanfaatan, pengamanan dan pemeliharaan, penilaian, pemindahtanganan, pemusnahan, penghapusan, penatausahaan, dan pembinaan, pengawasan, dan pengendalian.

Salah satu kegiatan dalam pengelolaan barang milik daerah adalah pemindahtanganan. Pasal 54 ayat (2) Peraturan Pemerintah No. 27 Tahun 2014 tentang Pengelolaan Barang Milik Negara/Daerah menetapkan bahwa pemindahtanganan barang milik negara/daerah dilakukan dengan cara, yaitu: a. penjualan, b. tukar-menukar, c. hibah, atau d. penyertaan modal Pemerintah Pusat atau Daerah. Berdasarkan ketentuan Pasal 54 ayat (2) Peraturan Pemerintah No. 27 Tahun 2014, barang milik daerah yang berupa tanah dapat dipindahtangankan kepada pihak lain melalui hibah. Berdasarkan uraian latar belakang masalah tersebut di atas, permasalahan yang hendak dikaji dan dirumuskan yaitu keabsahan hibah tanah yang dikuasai oleh Pemerintah Kabupaten/ Kota kepada perseorangan warga negara Indonesia.

\section{PEMBAHASAN}

\section{Status Tanah yang Dikuasai oleh Pemerintah Kabupaten/Kota}

Macam-macam hak atas tanah yang bersifat tetap disebutkan dalam UUPA, yaitu Hak Milik, Hak
Guna Usaha, Hak Guna Bangunan, Hak Pakai, Hak Sewa Untuk Bangunan, Hak Membuka Tanah, dan Hak Memungut Hasil Hutan. Hak atas tanah yang bersifat tetap adalah hak atas tanah ini akan tetap ada sepanjang UUPA masih berlaku atau belum diganti dengan undang-undang yang baru.

Dalam beberapa peraturan perundang-undangan disebutkan bahwa Pemerintah Kabupaten/Kota dapat menguasai atau subjek Hak Pakai. Pasal 42 UUPA menyebutkan bahwa yang dapat mempunyai Hak pakai adalah, pertama, warga negara Indonesia; kedua, orang asing yang berkedudukan di Indonesia; ketiga, badan hukum yang didirikan menurut hukum Indonesia dan berkedudukan di Indonesia; dan keempat, badan hukum asing yang mempunyai perwakilan di Indonesia. Pasal 39 Peraturan Pemerintah No. 40 Tahun 1996 menyebutkan bahwa yang dapat mempunyai Hak Pakai, adalah pertama, warga negara Indonesia; kedua, badan hukum yang didirikan menurut hukum Indonesia dan berkedudukan di Indonesia; ketiga, departemen, lembaga pemerintah non departemen, dan pemerintah daerah; keempat, badan keagamaan dan badan sosial; kelima, orang asing yang berkedudukan di Indonesia; keenam, badan hukum asing yang mempunyai perwakilan di Indonesia; ketujuh, perwakilan negara asing dan perwakilan badan internasional. Pasal 1 Peraturan Menteri Agraria No. 9 Tahun 1965 tentang Pelaksanaan Konversi Hak Penguasaan Atas Tanah Negara dan Kebijaksanaan Selanjutnya menyebutkan bahwa jika penguasaan hak atas tanah yang diberikan kepada departemen-departemen, direktoratdirektorat, dan daerah swatantra dipergunakan untuk kepentingan instansi-instansi itu sendiri dikonversi menjadi Hak Pakai. Pasal 1 huruf a Peraturan Menteri Agraria No. 1 Tahun 1966 tentang Pendaftaran Hak Pakai dan Hak Pengelolaan dinyatakan bahwa selain Hak Milik, Hak Guna Usaha, dan Hak Guna Bangunan, maka harus pula didaftarkan menurut ketentuan-ketentuan Peraturan Pemerintah No. 10 Tahun 1961 yaitu semua Hak Pakai, termasuk yang diperoleh departemen-departemen, direktoratdirektorat, dan daerah-daerah swatantra sebagai yang dimaksud dalam Peraturan Menteri Agraria No. 9 Tahun 1965. Pasal 39 Peraturan Menteri Negara Agraria/Kepala Badan Pertanahan Nasional No. 9 Tahun 1999 tentang Tata Cara Pemberian dan Pembatalan Pemberian Hak Atas Tanah Negara dan Hak Pengelolaan dinyatakan bahwa Hak Pakai dapat 
diberikan kepada, pertama, warga negara Indonesia; kedua, orang asing yang berkedudukan di Indonesia; ketiga, instansi pemerintah; keempat, badan hukum yang didirikan menurut hukum Indonesia dan berkedudukan di Indonesia; kelima, badan hukum asing yang mempunyai perwakilan di Indonesia.

Pengertian Hak Pakai disebutkan dalam Pasal 41 ayat (1) UUPA menegaskan bahwa hak untuk menggunakan atau memungut hasil dari tanah yang dikuasai langsung oleh negara atau tanah milik orang lain, yang memberi wewenang dan kewajiban yang ditentukan dalam pemberiannya oleh pejabat yang berwenang memberikannya atau dengan perjanjian dengan pemilik tanahnya, yang bukan perjanjian sewa menyewa tanah atau perjanjian pengolahan tanah, segala sesuatu asal tidak bertentangan dengan jiwa dan ketentuan-ketentuan Undang-Undang ini. Berdasarkan ketentuan Pasal 41 ayat (1) UUPA dapat dijelaskan bahwa Hak Pakai dapat untuk keperluan mendirikan bangunan yaitu pada kata menggunakan, dan atau dapat untuk keperluan pertanian, perikanan, peternakan, dan perkebunan, yaitu pada kata memungut hasil dari tanah, Hak Pakai dapat berasal dari tanah negara atau tanah milik orang lain, dan Hak Pakai yang berasal dari tanah negara terjadi dengan keputusan pemberian hak oleh pejabat yang berwenang memberikannya, Hak Pakai yang berasal dari tanah Hak Milik terjadi dengan perjanjian yang bukan perjanjian sewa menyewa tanah atau perjanjian pengolahan tanah.

Berdasarkan sifatnya, Hak Pakai dibagi menjadi 2 (dua), yaitu Pertama, Hak Pakai yang bersifat privat, adalah Hak Pakai yang dikuasai oleh Warga Negara Indonesia, orang asing yang berkedudukan di Indonesia, badan hukum yang didirikan menurut hukum Indonesia dan berkedudukan di Indonesia, misalnya Perseroan Terbatas (PT) dan Yayasan, dan badan hukum asing yang mempunyai perwakilan di Indonesia; dan Kedua, Hak Pakai yang bersifat publik, adalah Hak Pakai yang dikuasai oleh Lembaga Negara, Kementerian, Lembaga Pemerintah Non Kementerian, Badan Otoritas, Pemerintah Propinsi, Pemerintah Kabupaten/Kota, perwakilan negara asing, dan perwakilan badan internasional.

Hak Pakai yang bersifat privat berjangka waktu untuk pertama kali paling lama 25 (dua puluh lima) tahun, dapat diperpanjang untuk jangka waktu paling lama 20 (dua puluh) tahun, dan dapat diperbaharui untuk jangka waktu paling lama 25 (dua puluh lima) tahun. Hak Pakai yang bersifat publik tidak berjangka waktu tertentu, melainkan berlaku selama tanahnya dipergunakan untuk kepentingan pelaksanaan tugasnya.

A.P. Parlindungan menyatakan bahwa Hak Pakai yang dipunyai oleh badan hukum publik disebut Hak Pakai Publik ada right to use, yaitu menggunakannya untuk waktu yang tidak terbatas selama pelaksanaan tugas, namun tidak ada right of dispossal, yaitu tidak dapat dialihkan dalam bentuk apapun kepada pihak ketiga dan juga tidak dapat dijadikan objek Hak Tanggungan. ${ }^{1}$ Pihak yang menguasai tanah Hak Pakai yang bersifat publik mempunyai kewenangan untuk mempergunakan tanah Hak Pakai untuk waktu yang tidak terbatas dan berlaku selama tanah Hak Pakai dipergunakan untuk kepentingan pelaksanaan tugasnya, tetapi tidak mempunyai kewenangan memindahtangankan (mengalihkan) tanah Hak Pakai dalam bentuk apapun kepada pihak lain dan tidak menjadikan jaminan utang dengan dibebani Hak Tanggungan.

Hak Pakai yang dikuasai oleh Pemerintah Kabupaten/Kota mempunyai waktu yang tidak terbatas dan berlaku selama tanahnya dipergunakan untuk kepentingan pelaksanaan tugasnya. Menurut Penjelasan Pasal 45 ayat (1) Peraturan Pemerintah No. 40 Tahun 1996 tentang Hak Guna Usaha, Hak Guna Bangunan, dan Hak Pakai Atas Tanah, Hak Pakai yang diberikan untuk waktu yang tidak ditentukan selama tanahnya dipergunakan untuk keperluan tertentu tidak dapat dialihkan kepada pihak lain, akan tetapi dapat dilepaskan oleh pemegang haknya sehingga menjadi tanah negara untuk kemudian dimohon dengan hak baru oleh pihak lain tersebut. Hak Pakai yang dikuasai oleh Pemerintah Kabupaten/Kota bersifat right to use tidak right of dispossal. Hak Pakai yang dikuasai oleh Pemerintah Kabupaten/Kota tidak dapat dialihkan kepada pihak lain, akan tetapi dapat dilepaskan oleh Pemerintah Kabupaten/Kota untuk kepentingan pihak lain. Dengan pelepasan Hak Pakai oleh Pemerintah Kabupate/Kota berakibat Hak Pakai tersebut menjadi hapus dan kembali menjadi tanah negara atau tanah yang dikuasai langsung oleh negara.

Tanah Hak Pakai yang dikuasai oleh Pemerintah Kabupaten/Kota wajib didaftarkan oleh Pemerintah Kabupaten/Kota kepada Kantor Pertanahan

\footnotetext{
${ }^{1}$ A.P. Parlindungan, Maret-April 1991, "Beberapa Konsep tentang Hak-hak atas Tanah", Majalah CSIS, Tahun XX No. 2, Jakarta, h. 135.
} 
Kabupaten/Kota untuk diterbitkan Sertipikat Hak Pakai sebagai surat tanda bukti haknya. Dengan diterbitkan Sertipikat Hak Pakai, Pemerintah Kabupaten/Kota dengan mudah dapat membuktikan bahwa dirinya sebagai pemegang Hak Pakai.

Selain Hak Pakai, hak penguasaan atas tanah yang dapat dikuasai oleh Pemerintah Kabupaten/Kota adalah Hak Pengelolaan. Pengertian Hak Pengelolaan disebutkan dalam Pasal 1 angka 2 Peraturan Pemerintah No. 40 Tahun 1996 juncto Pasal 1 angka 4 Peraturan Pemerintah No. 24 Tahun 1997 tentang Pendaftaran Tanah, yaitu hak menguasai negara yang kewenangan pelaksanaannya sebagian dilimpahkan kepada pemegangnya. Pengertian Hak Pengelolaan yang lebih lengkap disebutkan dalam Pasal 2 ayat (3) Undang-Undang No. 20 Tahun 2000 tentang Perubahan Atas Undang-Undang Nomor 21 Tahun 1997 tentang Bea Perolehan Hak Atas Tanah dan Bangunan juncto Pasal 1 Peraturan Pemerintah No. 112 Tahun 2000 tentang Pengenaan Bea Perolehan Hak Atas Tanah dan Bangunan Karena Pemberian Hak Pengelolaan, yaitu hak menguasai dari negara atas tanah yang kewenangan pelaksanaannya sebagian dilimpahkan kepada pemegang haknya untuk merencanakan peruntukan dan penggunaan tanah, menggunakan tanah untuk keperluan pelaksanaan tugasnya, menyerahkan bagian-bagian tanah Hak Pengelolaan kepada pihak ketiga dan/atau bekerja sama dengan pihak ketiga.

Ketentuan yang menunjukkan bahwa Pemerintah Kabupaten/Kota sebagai pemegang hak atau subjek Hak Pengelolaan, adalah Pertama, Pasal 5 Peraturan Menteri Agraria No. 9 Tahun 1965 menyatakan bahwa Hak Pengelolaan dapat diberikan kepada Departemen, Direktorat, dan Daerah Swatantra; Kedua, Pasal 1 huruf b Peraturan Menteri Agraria No. 1 Tahun 1966 menyatakan bahwa Hak Pengelolaan dapat diberikan kepada Departemen, Direktorat, dan Daerah Swatantra; Ketiga, Pasal 67 Peraturan Menteri Negara Agraria/Kepala Badan Pertanahan Nasional No. 9 Tahun 1999 menyatakan bahwa Hak Pengelolaan dapat diberikan kepada instansi Pemerintah termasuk Pemerintah Daerah, Badan Usaha Milik Negara, Badan Usaha Milik Daerah, PT Persero, Badan Otorita, dan badan-badan hukum Pemerintah lainnya yang ditunjuk oleh Pemerintah.

Kewenangan yang diberikan kepada pemegang Hak Pengelolaan terhadap tanahnya, adalah pertama, merencanakan peruntukan dan penggunaan tanah; kedua, mempergunakan tanah Hak Pengelolaan untuk keperluan pelaksanaan tugasnya; dan ketiga, menyerahkan bagian-bagian tanah Hak Pengelolaan kepada pihak ketiga dan atau bekerja sama dengan pihak ketiga.

Berdasarkan sifatnya, kewenangan dalam Hak Pengelolaan dibagi menjadi 2 (dua), yaitu Pertama, kewenangan yang bersifat internal, adalah kewenangan merencanakan peruntukan dan penggunaan tanah, dan kewenangan mempergunakan tanah untuk keperluan pelaksanaan tugasnya; dan Kedua, kewenangan yang bersifat eksternal, adalah kewenangan menyerahkan bagian-bagian tanah Hak Pengelolaan kepada pihak ketiga dan atau bekerja sama dengan pihak ketiga.

Tanah Hak Pengelolaan yang dikuasai oleh Pemerintah Kabupaten/Kota wajib didaftarkan oleh Pemerintah Kabupaten/Kota kepada Kantor Pertanahan Kabupaten/Kota untuk diterbitkan Sertipikat Hak Pengelolaan sebagai surat tanda bukti haknya. Dengan diterbitkan Sertipikat Hak Pengelolaan, Pemerintah Kabupaten/Kota dengan mudah dapat membuktikan bahwa dirinya sebagai pemegang Hak Pengelolaan.

Kewenangan berupa penyerahan bagian-bagian tanah Hak Pengelolaan yang dikuasai oleh Pemerintah Kabupaten/Kota dipergunakan kepada pihak ketiga, diatur dalam Pasal 4 ayat (2) Peraturan Menteri Negara Agraria/Kepala Badan Pertanahan Nasional No. 9 Tahun 1999 menegaskan bahwa "Dalam hak tanah yang dimohon merupakan tanah Hak Pengelolaan, pemohon harus terlebih dahulu memperoleh penunjukan berupa perjanjian penggunaan tanah dari pemegang Hak Pengelolaan". Pihak ketiga yang mempergunakan tanah Hak Pengelolaan yang dikuasai oleh Pemerintah Kabupaten/Kota harus dibuatkan Perjanjian Penggunaan Tanah (yang selanjutnya disebut PPT) antara pemegang Hak Pengelolaan yaitu Pemerintah Kabupaten/Kota dan pihak ketiga.

Maria S.W. Sumardjono menyatakan, bahwa untuk memperoleh Hak Guna Bangunan di atas Hak Pengelolaan, pihak ketiga harus memperoleh persetujuan dari pemegang Hak Pengelolaan yang dimuat dalam Perjanjian Penyerahan, Penggunaan, dan Pengurusan Hak Atas Tanah, karena perjanjian itu 
merupakan alas hak pemberian Hak Guna Bangunan di atas Hak Pengelolaan. ${ }^{2}$

Kewenangan berupa bekerjasama antara Pemerintah Kabupaten/Kota sebagai pemegang Hak Pengelolaan dengan pihak ketiga dapat berupa Perjanjian Build, Operate, and Transfer (yang selanjutnya disebut BOT). Maria S.W. Sumardjono memberikan pengertian Perjanjian BOT yaitu merupakan perjanjian dua pihak, dimana pihak pertama menyerahkan penggunaan tanahnya untuk didirikan suatu bangunan di atasnya oleh pihak kedua, dan pihak kedua berhak mengoperasikan atau mengelola bangunan tersebut dalam jangka waktu tertentu, dengan memberikan fee atau tanpa fee kepada pihak pertama, dan pihak kedua wajib mengembalikan tanah beserta bangunan di atasnya dalam keadaan dapat dan siap dioperasikan oleh pihak pertama setelah jangka waktu operasional berakhir. ${ }^{3}$

Perjanjian Bangun Guna Serah. Pengertian Bangun Guna Serah disebutkan dalam Pasal 1 angka 14 Peraturan Pemerintah No. 27 Tahun 2014, yaitu pemanfaatan barang milik negara/daerah berupa tanah oleh pihak lain dengan cara mendirikan bangunan dan/atau sarana berikut fasilitasnya, kemudian didayagunakan oleh pihak lain dalam jangka waktu tertentu yang telah disepakati, untuk selanjutnya diserahkan kembali tanah beserta bangunan dan/ atau sarana berikut fasilitasnya setelah berakhirnya jangka waktu. Perjanjian Bangun Guna Serah adalah perjanjian yang dibuat antara Pemerintah Kabupaten/ Kota sebagai pemegang Hak Pengelolaan dengan pihak ketiga, yang berisi pihak ketiga diberikan hak untuk mendirikan bangunan yang bersifat komersial di atas tanah Hak Pengelolaan, bangunan tersebut didayagunakan oleh pihak ketiga dalam jangka waktu tertentu yang disepakati kedua belah pihak, dan pada akhir masa perjanjian, tanah dan bangunan diserahkan kembali oleh pihak ketiga kepada Pemerintah Kabupaten/Kota sebagai pemegang Hak Pengelolaan.

Tanah Hak Pengelolaan yang dikuasai oleh Pemerintah Kabupaten/Kota dapat dipergunakan oleh pihak ketiga. Kewenangan Pemerintah Kabupaten/ Kota sebagai pemegang Hak Pengelolaan untuk

${ }^{2}$ Maria S.W. Sumardjono, September 2007, "Hak Pengelolaan: Perkembangan, Regulasi, dan Implementasinya", Jurnal MIMBAR HUKUM, Edisi Khusus, Fakultas Hukum Universitas Gadjah Mada, Yogyakarta, h. 34.

${ }^{3}$ Maria S.W. Sumardjono, Tanah dalam Perspektif Hak Ekonomi Sosial dan Budaya, Kompas, Jakarta, 2008, h. 208. menyerahkan bagian-bagian tanah Hak Pengelolaan kepada pihak ketiga dan atau bekerja sama dengan pihak ketiga mensyaratkan tanah Hak Pengelolaan harus sudah bersertipikat atas nama Pemerintah Kabupaten/Kota.

\section{Pengaturan Hibah Tanah dalam Peraturan Perundang-undangan}

Beberapa peraturan perundang-undangan yang menyebutkan tentang hibah, adalah Pertama, Pasal 26 ayat (1) UUPA menyebutkan bahwa jual beli, penukaran, penghibahan, pemberian dengan wasiat, pemberian menurut adat, dan perbuatan-perbuatan lain yang dimaksudkan untuk memindahkan Hak Milik serta pengawasannya diatur dengan Peraturan Pemerintah; Kedua, Pasal 16 ayat (2) huruf d Peraturan Pemerintah No. 40 Tahun 1996 menyebutkan bahwa peralihan Hak Guna Usaha terjadi dengan cara hibah; Ketiga, Pasal 34 ayat (2) huruf d Peraturan Pemerintah No. 40 Tahun 1996 menyebutkan bahwa peralihan Hak Guna Bangunan terjadi dengan cara hibah; Keempat, Pasal 54 ayat (3) huruf d Peraturan Pemerintah No. 40 Tahun 1996 menyebutkan bahwa peralihan Hak Pakai terjadi karena hibah; Kelima, Pasal 37 ayat (1) Peraturan Pemerintah No. 24 Tahun 1997 tentang Pendaftaran Tanah menyebutkan bahwa peralihan hak atas tanah dan hak milik atas satuan rumah susun melalui jual beli, tukar menukar, hibah, pemasukan dalam perusahaan dan perbuatan hukum pemindahan hak lainnya, kecuali pemindahan hak melalui lelang hanya dapat didaftarkan jika dibuktikan dengan akta yang dibuat oleh Pejabat Pembuat Akta Tanah yang berwenang menurut ketentuan peraturan perundangundangan yang berlaku; Keenam, Pasal 2 ayat (2) Peraturan Pemerintah No. 37 Tahun 1998 tentang Peraturan Jabatan Pejabat Pembuat Akta Tanah menyebutkan bahwa perbuatan hukum sebagaimana dimaksud pada ayat (1) adalah a. jual beli, b. tukar menukar, c. hibah, d. pemasukan ke dalam perusahaan (inbreng), e. pembagian hak bersama, f. pemberian Hak Guna Bangunan/Hak Pakai atas tanah Hak Milik, g. pemberian Hak Tanggungan, h. pemberian kuasa membebankan Hak Tanggungan; Ketujuh, Pasal 95 ayat (1) huruf c Peraturan Menteri Negara Agraria/ Kepala Badan Pertanahan Nasional No. 3 Tahun 1997 menyebutkan bahwa akta tanah yang dibuat oleh Pejabat Pembuat Akta Tanah untuk dijadikan dasar pendaftaran perubahan data pendaftaran tanah adalah akta hibah; Kedelapan, Pasal 2 Peraturan Kepala 
Badan Pertanahan Nasional RI No. 1 Tahun 2006 tentang Ketentuan Pelaksanaan Peraturan Pemerintah Nomor 37 Tahun 1998 tentang Peraturan Jabatan Pejabat Pembuat Akta Tanah menyebutkan bahwa perbuatan hukum sebagaimana dimaksud pada ayat (1) adalah a. jual beli, b. tukar menukar, c. hibah, d. pemasukan ke dalam perusahaan (inbreng), e. pembagian hak bersama, f. pemberian Hak Guna Bangunan/Hak Pakai atas tanah Hak Milik, g. pemberian Hak Tanggungan, h. pemberian kuasa membebankan Hak Tanggungan. Dari peraturan perundang-undangan tersebut hanya disebutkan hibah, tetapi tidak memberikan pengertian apa yang dimaksudkan dengan hibah.

Urip Santoso menyatakan bahwa yang dimaksud dengan hibah hak atas tanah adalah perbuatan hukum berupa penyerahan hak atas tanah untuk selamalamanya oleh pemilik tanah atau pemegang hak atas tanah kepada pihak lain tanpa pembayaran sejumlah uang dari penerima hak atas tanah kepada pemilik tanah atau pemegang hak atas tanah. Pengertian hibah dalam kaitannya dengan pengelolaan barang milik negara/daerah disebutkan dalam Pasal 1 angka 20 Peraturan Pemerintah No. 27 Tahun 2014, yaitu pengalihan kepemilikan barang dari Pemerintah Pusat kepada Pemerintah Daerah, dari Pemerintah Daerah kepada Pemerintah Pusat, antar Pemerintah Daerah, atau dari Pemerintah Pusat/Pemerintah Daerah kepada pihak lain, tanpa memperoleh penggantian.

Hibah tanah tidak tunduk pada Buku III Burgerlijk Wetboek (yang selanjutnya disebut dengan BW), melainkan tunduk pada Hukum Tanah Nasional. Hibah tanah bukan merupakan perjanjian antara pemberi hibah dan penerima hibah, melainkan merupakan perbuatan hukum untuk menyerahkan hak atas tanah untuk selama-lamanya oleh pemegang hak atas tanah sebagai pemberi hibah kepada pihak lain sebagai penerima hibah.

Objek hibah dapat berupa benda tidak bergerak yaitu hak atas tanah, atau benda bergerak, misalnya kendaraan bermotor. Hak atas tanah yang dapat dihibahkan oleh pemegang haknya kepada pihak lain adalah Hak Milik, Hak Guna Usaha, Hak Guna Bangunan, dan Hak Pakai atas tanah.

Hibah hak atas tanah merupakan salah satu contoh peralihan hak atas tanah yang berbentuk dialihkan. Ada 2 (dua) bentuk peralihan hak atas tanah, yaitu pertama, beralih, yaitu berpindahnya hak atas tanah dari pemegang haknya kepada pihak lain karena peristiwa hukum (hak atas tanah berpindah karena pemegang haknya meninggal dunia) atau berpindah melalui pewarisan. Berpindahnya hak atas tanah ini karena hukum, artinya dengan meninggal dunianya pemegang hak atas tanah, maka ahli warisnya memperoleh hak atas tanah; kedua, dialihkan, yaitu berpindahnya hak atas tanah dari pemegang haknya kepada pihak lain karena suatu perbuatan hukum yang sengaja dilakukan dengan tujuan agar pihak lain memperoleh hak atas tanah. Perbuatan hukum tersebut adalah jual beli, tukar menukar, hibah, pemasukan dalam modal perusahaan (inbreng), dan lelang.

Hibah tanah merupakan peralihan hak atas tanah yang berbentuk dialihkan. Hibah tanah merupakan perbuatan hukum berupa penyerahan hak atas tanah untuk selama-lamanya oleh pemegang hak atas tanah sebagai pemberi hibah kepada pihak lain sebagai penerima hibah. Dengan hibah tanah berakibat hak atas tanah berpindah dari pemegang hak atas tanah sebagai pemberi hibah kepada pihak lain sebagai penerima hibah. Dalam hibah tanah tidak ada pembayaran uang dari penerima hibah kepada pemberi hibah.

Untuk keperluan pendaftaran tanah, hibah tanah wajib dibuktikan dengan akta yang dibuat oleh dan dihadapan Pejabat Pembuat Akta Tanah (yang selanjutnya disebut PPAT) yang berwenang. Ketentuan ini ditetapkan dalam Pasal 37 ayat (1) Peraturan Pemerintah No. 24 Tahun 1997 menegaskan bahwa Peralihan hak atas tanah dan hak milik atas satuan rumah susun melalui jual beli, tukar menukar, hibah, pemasukan dalam perusahaan dan perbuatan hukum pemindahan hak lainnya, kecuali pemindahan hak melalui lelang hanya dapat didaftarkan jika dibuktikan dengan akta yang dibuat oleh Pejabat Pembuat Akta Tanah yang berwenang menurut ketentuan peraturan perundang-undangan yang berlaku. Akta hibah tanah yang dibuat oleh PPAT yang berwenang sebagai bukti telah dilaksanakan hibah oleh pemberi hibah dan penerima hibah. Dengan telah dibuatnya akta hibah tanah oleh PPAT yang berwenang, maka berakibat hak atas tanah berpindah dari pemberi hibah kepada penerima hibah.

Pengertian PPAT disebutkan dalam Pasal 1 angka 1 Peraturan Pemerintah No. 37 Tahun 1998 juncto Pasal 1 angka 1 Peraturan Kepala Badan Pertanahan Nasional RI No. 1 Tahun 2006, yaitu pejabat umum yang diberi kewenangan untuk membuat akta-akta 
otentik mengenai perbuatan hukum tertentu mengenai hak atas tanah atau hak milik atas satuan rumah susun. Akta yang dibuat oleh PPAT dinamakan Akta PPAT. Pengertian PPAT disebutkan dalam Pasal 1 angka 4 Peraturan Pemerintah No. 37 Tahun 1998 juncto Pasal 1 angka 4 Peraturan Kepala Badan Pertanahan Nasional RI No. 1 Tahun 2006, yaitu akta yang dibuat oleh PPAT sebagai bukti telah dilaksanakan perbuatan hukum tertentu mengenai hak atas tanah atau hak milik atas satuan rumah susun.

Pembuatan akta hibah tanah, kewenangannya diserahkan kepada PPAT. Selain hibah, pembuatan akta yang kewenangannya diserahkan kepada PPAT, adalah jual beli, tukar menukar, pemasukan dalam modal perusahaan (inbreng), pembagian hak bersama, pemberian Hak Guna Bangunan/Hak Pakai atas tanah Hak Milik, pemberian Hak Tanggungan, dan pemberian kuasa membebankan Hak Tanggungan.

Pihak-pihak yang terkait dalam pendaftaran hibah hak atas tanah, adalah pertama, Pemberi Hibah, yaitu pemegang hak atas tanah yang memberikan hak atas tanahnya kepada pihak lain; kedua, Penerima Hibah, yaitu orang yang menerima hibah hak atas tanah dari pemberi hibah; ketiga, PPAT yaitu pejabat umum yang diberi kewenangan untuk membuat akta hibah hak atas tanah; keempat, Kantor Pertanahan Kabupaten/Kota, yaitu instansi Pemerintah yang melakukan pendaftaran hibah hak atas tanah.

Hibah hak atas tanah yang didaftarkan ke Kantor Pertanahan Kabupaten/Kota dimaksudkan untuk mengubah nama pemegang hak atas tanah dari atas nama pemberi hibah menjadi atas nama penerima hibah. Dengan pendaftaran hibah hak atas tanah, maka terwujud jaminan kepastian hukum dan perlindungan hukum, dan terwujud tertib administrasi pertanahan.

\section{Keabsahan Hibah Tanah Pemerintah Kabupaten/ Kota}

Pada saat ini, pengelolaan barang milik negara/daerah diatur dalam Peraturan Pemerintah No. 27 Tahun 2014 tentang Pengelolaan Barang Milik Negara/Daerah. Peraturan Pemerintah No. 27 Tahun 2014 mencabut dan menyatakan tidak berlaku Peraturan Pemerintah No. 6 Tahun 2006 tentang Pengelolaan Barang Milik Negara/Daerah sebagaimana telah diubah oleh Peraturan Pemerintah No. 38 Tahun 2008 tentang Perubahan Atas Peraturan Pemerintah Nomor 6 Tahun 2006 tentang Pengelolaan
Barang Milik Negara/Daerah. Peraturan Pemerintah No. 6 Tahun 2006 melaksanakan Undang-Undang No. 1 Tahun 2004 tentang Perbendaharaan Negara. Peraturan Pemerintah No. 6 Tahun 2006 dilaksanakan oleh Peraturan Menteri Dalam Negeri No. 17 Tahun 2007 tentang Pedoman Teknis Pengelolaan Barang Milik Daerah.

Dalam Peraturan Pemerintah No. 27 Tahun 2014 ditetapkan bahwa barang milik daerah dibagi menjadi 2 (dua), yaitu pertama, barang milik daerah berupa tanah dan/atau bangunan; kedua, barang milik daerah berupa selain tanah dan/atau bangunan. Barang milik daerah adalah barang yang dimiliki oleh Pemerintah Provinsi, atau Pemerintah Kabupaten/Kota. Barang milik Pemerintah Kabupaten/Kota yang berupa tanah statusnya adalah Hak Pakai dan Hak Pengelolaan.

Pasal 3 ayat (2) Peraturan Pemerintah No. 27 Tahun 2014 menetapkan bahwa pengelolaan barang milik negara/daerah meliputi perencanaan kebutuhan dan penganggaran, pengadaan dan penggunaan, pemanfaatan, pengamanan serta pemeliharaan, penilaian, pemindahtanganan dan pemusnahan, penghapusan, penatausahaan serta pembinaan, pengawasan, dan pengendalian. Salah satu kegiatan dalam pengelolaan barang milik negara atau daerah adalah pemindahtanganan. Pasal 54 ayat (1) Peraturan Pemerintah No. 27 Tahun 2014 menetapkan bahwa barang milik negara atau daerah yang tidak diperlukan bagi penyelenggaraan tugas pemerintahan negara atau daerah dapat dipindahtangankan. Selanjutnya Pasal 54 ayat (2) Peraturan Pemerintah No. 27 Tahun 2014 menetapkan bahwa pemindahtanganan barang milik negara atau daerah dilakukan dengan cara penjualan, tukar menukar, hibah, atau penyertaan modal Pemerintah Pusat atau Daerah.

Salah satu bentuk pemindahtanganan barang milik negara atau daerah adalah hibah. Pasal 68 ayat (1) Peraturan Pemerintah No. 27 Tahun 2014 menegaskan bahwa hibah barang milik negara/daerah dilakukan dengan pertimbangan untuk kepentingan sosial, budaya, keagamaan, kemanusiaan, pendidikan yang bersifat non komersial, dan penyelenggaraan pemerintahan negara/daerah. Pasal 68 ayat (2) Peraturan Pemerintah No. 27 Tahun 2014 menetapkan syarat hibah barang milik negara/daerah, yaitu Pertama, bukan merupakan barang rahasia negara; Kedua, bukan barang yang menguasai hajat hidup orang banyak; dan Ketiga, tidak diperlukan 
dalam penyelenggaraan tugas dan fungsi dan penyelenggaraan pemerintahan negara/daerah.

Pasal 69 ayat (1) Peraturan Pemerintah No. 27 Tahun 2014 menegaskan bahwa macam barang milik negara/daerah yang dapat dihibahkan, yaitu Pertama, tanah dan/atau bangunan yang berada pada pengelola barang untuk barang milik negara, atau yang telah diserahkan kepada gubernur/bupati/walikota untuk barang milik daerah; Kedua, tanah dan/atau bangunan yang berada pada pengguna barang; atau Ketiga, selain tanah dan/atau bangunan.

Barang milik negara atau daerah yang dapat dihibahkan antara lain adalah barang milik daerah berupa tanah dan/atau bangunan yang diserahkan kepada Bupati/Walikota, atau tanah dan/atau bangunan yang berada pada penggunaan barang.

Kalau barang milik daerah yang dihibahkan oleh Pemerintah Kabupaten/Kota berupa tanah dan/ atau bangunan, maka tanahnya berstatus Hak Pakai atau Hak Pengelolaan sebab status tanah yang dapat dikuasai oleh Pemerintah Kabupaten/Kota adalah Hak Pakai dan Hak Pengelolaan. Tanah Hak Pakai dan Hak Pengelolaan Pemerintah Kabupaten/Kota yang dihibahkan ada yang masih dikuasai oleh Pemerintah Kabupaten/Kota atau dikuasai oleh pihak lain.

Peraturan Pemerintah No. 27 Tahun 2014 tidak mengatur tata cara dan bukti dilakukan hibah barang milik daerah berupa tanah dan/atau bangunan oleh Pemerintah Kabupaten/Kota kepada pihak lain. Kalau benda yang dihibahkan oleh Pemerintah Kabupaten/ Kota berupa tanah kepada pihak lain, maka tata cara (prosedur) hibahnya tunduk pada Hukum Tanah Nasional yang diatur secara khusus dalam pendaftaran tanah.

Ada 2 (dua) macam syarat sahnya pendaftaran hibah tanah yang harus dipenuhi oleh pemberi hibah dan penerima hibah, yaitu Pertama, Syarat Materiil. Syarat materil bagi pemberi hibah hak atas tanah adalah pemberi hibah berhak dan berwenang menghibahkan hak atas tanahnya kepada pihak lain. Syarat materiil bagi penerima hak atas tanah adalah harus memenuhi syarat sebagai subjek hak atas tanah yang menjadi objek hibah; Kedua, Syarat Formal. Hibah hak atas tanah harus dibuktikan dengan akta yang dibuat oleh PPAT sebagaimana ditetapkan dalam Pasal 37 ayat (1) Peraturan Pemerintah No. 24 Tahun 1997 menegaskan bahwa Peralihan hak atas tanah dan hak milik atas satuan rumah susun melalui jual beli, tukar menukar, hibah, pemasukan dalam modal perusahaan dan perbuatan hukum pemindahan hak lainnya, kecuali melalui lelang hanya dapat didaftarkan jika dibuktikan dengan akta PPAT yang berwenang menurut ketentuan yang diatur dalam peraturan perundang-undangan yang berlaku.

Berdasarkan 2 (dua) syarat sahnya pendaftaran hibah hak atas tanah dapat dijelaskan bahwa dari aspek syarat materiil, Pemerintah Kabupaten atau Kota sebagai pemegang Hak Pakai dan Hak Pengelolaan tidak mempunyai kewenangan untuk menghibahkan Hak Pakai dan Hak Pengelolaannya kepada pihak lain. Kewenangan Pemerintah Kabupaten/Kota terhadap tanah Hak Pakainya adalah mempergunakan tanah Hak Pakai selama tanahnya dipergunakan untuk keperluan pelaksanaan tugasnya. Kewenangan Pemerintah Kabupaten atau Kota terhadap Hak Pengelolaannya adalah merencanakan peruntukan dan penggunaan tanah, mempergunakan tanah untuk keperluan pelaksanaan tugasnya, menyerahkan bagian-bagian tanah Hak Pengelolaan kepada pihak ketiga dan atau bekerja sama dengan pihak ketiga. Berdasarkan ketentuan Penjelasan Pasal 45 ayat (1) Peraturan Pemerintah No. 40 Tahun 1996 menegaskan bahwa Hak Pakai yang diberikan untuk waktu yang tidak ditentukan selama tanahnya dipergunakan untuk keperluan tertentu tidak dapat dialihkan kepada pihak lain, akan tetapi dapat dilepaskan oleh pemegang haknya sehingga menjadi tanah negara untuk kemudian dimohon dengan hak baru oleh pihak lain tersebut. Atas dasar ketentuan Penjelasan Pasal 45 ayat (1) Peraturan Pemerintah No. 40 Tahun 1996 menegaskan bahwa Hak Pakai yang dikuasai oleh Pemerintah Kabupaten atau Kota adalah Hak Pakai yang diberikan untuk jangka waktu yang tidak ditentukan yang berlaku selama tanahnya dipergunakan untuk keperluan pelaksanaan tugasnya tidak dapat dialihkan melalui hibah kepada pihak lain. Pemerintah Kabupaten/Kota yang menguasai tanah Hak Pengelolaan tidak mempunyai kewenangan untuk mengalihkan Hak Pengelolaannya melalui hibah kepada pihak lain, melainkan Pemerintah Kabupaten/Kota dapat menyerahkan bagian-bagian tanah Hak Pengelolaannya kepada pihak lain. Dari aspek materiil, Pemerintah Kabupaten/Kota tidak memenuhi syarat untuk menghibahkan tanah Hak Pakai dan Hak Pengelolaannya kepada pihak lain. Dari penerima hibah yang berupa perseorangan warga negara Indonesia tidak memenuhi syarat sebagai subjek Hak Pakai dan Hak Pengelolaan Pemerintah 
Kabupaten/Kota yang menjadi objek hibah. Dari aspek syarat formal, kalau dari aspek syarat materiil tidak dipenuhi oleh Pemerintah Kabupaten/Kota sebagai pemberi hibah dan perseorangan warga negara Indonesia sebagai penerima hibah, maka syarat formalnya tidak akan dapat dipenuhi, yaitu hibah tanahnya tidak dapat dibuktikan dengan akta PPAT yang berwenang sebagaimana ditetapkan dalam Pasal 37 ayat (1) Peraturan Pemerintah No. 24 Tahun 1997. Berdasarkan ketentuan Pasal 39 ayat (1) huruf c Peraturan Pemerintah No. 24 Tahun 1997, PPAT berwenang menolak membuat akta apabila salah satu atau para pihak yang akan melakukan suatu perbuatan hukum yang bersangkutan atau salah satu saksi tidak berhak atau tidak memenuhi syarat untuk bertindak demikian. PPAT berwenang menolak tidak membuat akta hibah apabila Pemerintah Kabupaten atau Kota sebagai pemberi hibah dan warga negara Indonesia sebagai penerima hibah tidak memenuhi syarat materiil untuk melakukan hibah hak atas tanah.

Tanah yang dikuasai oleh Pemerintah Kabupaten/ Kota yang berstatus Hak Pakai atau Hak Pengelolaan tidak memenuhi syarat materiil dan syarat formal untuk dihibahkan kepada warga negara Indonesia sebab tanah Hak Pakai dan Hak Pengelolaan yang dikuasai oleh Pemerintah Kabupaten/Kota tidak dapat dipindahtangankan melalui hibah kepada pihak lain. Tanah Hak Pakai dan Hak Pengelolaan yang dikuasai oleh Pemerintah Kabupaten/Kota dapat dilepaskan atau diserahkan kepada pihak lain dengan pemberian ganti kerugian oleh pihak yang memperoleh tanah kepada Pemerintah Kabupaten/Kota.

\section{PENUTUP}

\section{Kesimpulan}

Hibah yang objeknya hak atas tanah tidak tunduk pada Buku III Burgerlijk Wet (BW), melainkan tunduk pada Hukum Tanah Nasional, yaitu prosedur (tata caranya) diatur dalam Peraturan Pemerintah No. 24 Tahun 1997 tentang Pendaftaran Tanah.

Hibah hak atas tanah merupakan contoh peralihan hak atas tanah yang berbentuk dialihkan (pemindahan hak). Hibah hak atas tanah adalah perbuatan hukum berupa penyerahan hak atas tanah untuk selamalamanya oleh pemilik tanah atau pemegang hak atas tanah kepada pihak lain tanpa pembayaran sejumlah uang dari penerima hak atas tanah kepada pemilik tanah atau pemegang hak atas tanah.
Tanah Hak Pakai dan Hak Pengelolaan yang dikuasai oleh Pemerintah Kabupaten/Kota tidak memenuhi syarat sah, baik syarat materiil dan syarat formal untuk dihibahkan kepada warga negara Indonesia. Pemerintah Kabupaten/Kota sebagai pemegang Hak Pakai dan Hak Pengelolaan tidak mempunyai kewenangan untuk memindahtangankan melalu hibah kepada pihak lain. Hibah tanah Hak Pakai dan Hak Pengelolaan tidak akan dapat dibuktikan dengan akta PPAT.

\section{Rekomendasi}

Peraturan Pemerintah No. 27 Tahun 2014 tentang Pengelolaan Barang Milik Negara/Daerah harus ditinjau kembali sebab pemindahtanganan barang milik negara/daerah yang berupa hak atas tanah tidak dapat dipindahtangankan melalui hibah menurut ketentuan-ketentuan dalam pendaftaran tanah yang diatur dalam Peraturan Pemerintah No. 24 Tahun 1997 tentang Pendaftaran Tanah.

\section{DAFTAR PUSTAKA}

\section{Peraturan Perundang-undangan:}

Undang-Undang No. 5 Tahun 1960 tentang Peraturan Dasar Pokok-pokok Agraria.

Undang-Undang No. 20 Tahun 2000 tentang Perubahan atas Undang-Undang Nomor 21

Tahun 1997 tentang Bea Perolehan Hak atas Tanah dan Bangunan.

Peraturan Pemerintah No. 40 Tahun 1996 tentang Hak Guna Usaha, Hak Guna Bangunan, Hak Pakai atas Tanah.

Peraturan Pemerintah No. 24 Tahun 1997 tentang Pendaftaran Tanah.

Peraturan Pemerintah No. 37 Tahun 1998 tentang Peraturan Jabatan Pejabat Pembuat Akta Tanah.

Peraturan Pemerintah No. 112 Tahun 2000 tentang Pengenaan Bea Perolehan Hak atas Tanah dan Bangunan Karena Pemberian Hak Pengelolaan. Peraturan Pemerintah No. 27 Tahun 2014 tentang Pengelolaan Barang Milik Negara/Daerah.

Peraturan Menteri Agraria No. 9 Tahun 1965 tentang Pelaksanaan Konversi Hak Penguasaan atas Tanah Negara dan Kebijaksanaan Selanjutnya.

Peraturan Menteri Agraria No. 1 Tahun 1966 tentang Pendaftaran Hak Pakai dan Hak Pengelolaan.

Peraturan Menteri Negara Agraria/Kepala Badan Pertanahan Nasional No. 9 Tahun 1999 tentang 
Tata Cara Pemberian dan Pembatalan Pemberian

Hak atas Tanah Negara dan Hak Pengelolaan. Peraturan Kepala Badan Pertanahan Nasional RI No.

1 Tahun 2006 tentang Ketentuan Pelaksanaan

Peraturan Pemerintah Nomor 37 Tahun 1998

tentang Peraturan Jabatan Pejabat Pembuat Akta

Tanah.

\section{Buku/Jurnal:}

Parlindungan, A.P. Maret-April 1991. "Beberapa Konsep tentang Hak-hak Atas Tanah". Majalah CSIS. Tahun XX No. 2. Jakarta.

Sumardjono, Maria S.W. September 2007. "Hak Pengelolaan: Perkembangan, Regulasi, dan Implementasinya". Jurnal MIMBAR HUKUM, Edisi Khusus, Yogyakarta: Fakultas Hukum Universitas Gadjah Mada.

2008. Tanah dalam Perspektif Hak Ekonomi Sosial dan Budaya. Jakarta: Kompas. 